\title{
Competitiveness of the Regions in the Czech Republic from the Perspective of Disaster Risk Financing
}

- Alena Oulehlova, Ales Kudlak, Rudolf Urban, Eva Hoke

\begin{abstract}
Mitigation of the impact of disasters and increasing resilience represent an inseparable part of the competitiveness of regions that cannot be implemented without a necessary resource framework. The paper focuses on the issue of financing individual phases of disaster management at the level of regions in the Czech conditions. The article is based on the assumption that public authorities do not systematically plan funds for dealing with crisis situations in the expenditure part of the budget, thereby not supporting the structural and functional conditions of territorial attractiveness, security and sustainability. The aim of the article is to propose a unique calculation of the minimum fund allocation for individual phases of disaster risk reduction at the regional level. The calculation concept is based on the value of the property owned by the region, the number of crisis situations predicted in the region, the number of crisis situations predicted in the Czech Republic, the administrative territory of the region and the total expenditures of the regional budget. The article presents a specific national approach to the public fund allocation to the individual disaster risk management phases, providing competitive administration and progressive and resilient development of the region. Based on the originally elaborated calculation, a comparative analysis of the expenditure part of 13 regional budgets for the 20132019 period was performed. The premise on the insufficient financing of disaster management was confirmed, although the Crisis Management Act imposes this obligation. The results showed that the most underfunded area was the implementation phase.
\end{abstract}

Keywords: allocation of funds, crisis situation, disaster, financing, region, resilience of the territory JEL Classification: H72, H12

Received: April, 2021

1st Revision: October, 2021

Accepted: November, 2021

\section{INTRODUCTION}

The growing incidence of natural and anthropogenic disasters has a negative impact on the population (Marin \& Modica, 2017; Marin et al., 2021; Boccard, 2021), property, infrastructure and environment. Damage to private and public capital resulting from disasters can cause temporary or permanent productivity loss and debt distress (Marto et al., 2018), which can cause short-term and long-term loss of regional competitiveness. 
National governments have primary responsibility for preventing and reducing disaster risks. (United Nations, 2015). Due to the application of the subsidiarity principle in the public administration of all EU Member States, decision-making powers and responsibilities for disaster risk management are transferred to the level of the self-governing territorial units closer to the citizens. No phase of disaster risk management can be successfully implemented without allocating funds. Governance and financial capacity represent the foundation block to build and maintain resilience (UNDRR, 2019).

International strategic documents for disaster risk reduction and scientific literature financing issues can be found in connection with financial assistance (Weber \& Musshoff, 2021; De Juan et al., 2020), allocation of funds (Kikuta, 2019; De Juan et al., 2020), financial instruments, donations (Brown et al., 2012; Oosterhof et al., 2009), financial institutions, financial support and insurance (Wu, 2020; Paleari, 2019; Ma et al., 2021; Zhao et al., 2020; Sturm \& Oh, 2010) and budget (Brodmerkel et al., 2020). Other links related to the topic include affordability, cost-effective provision of income opportunities and indebted countries, which draws attention to issues of competitiveness and the overall socio-economic stability of the region. Taylor et al. (2014), for example, drew attention to the problems with the lack of funding at a local level.

Awareness of the seriousness of the disaster risk situation has led the Czech Republic (CR) to accept the commitments of the Sendai Framework (United Nations, 2015). It is not only a matter of accepting commitments but also of fulfilling them comprehensively, i.e. including the provision of funds for disaster risk management at all levels of public administration.

The authors of the article emphasize the importance of disaster risk financing (DRF) at the regional level as a basis for increasing the competitiveness of the region. At the same time, they draw attention to the need for comprehensive financing of all phases of disaster risk management. The article fills the existing gap in the research of optimal DRF of regions in the Czech Republic. It proposes an innovative approach based on calculating funds in the regional budget.

The paper has the following structure. The article in Chapter 2 provides an overview of the scientific literature in the field of DRF. It explains the link to the competitiveness of the region and the resilience of the territory. Then the goal, methodology and input data are explained. Chapter 4 presents a proposal to calculate the minimum number of financial resources for addressing the individual disaster phases and the results obtained after dealing with the research tasks.

\section{THEORETICAL BACKGROUND}

This chapter defines the essential relationships and contexts, describing in more detail the competitiveness of the regions of the Czech Republic from the perspective of DRF.

\subsection{The link between competitiveness, territorial resilience and disaster risk financing}

Competitiveness is focused on the high level of productivity (Schwab \& Zadihi, 2020) of production factors. In order for production factors to be used at a sustainable level, their protection against threats must be provided. The public sector and its institutions, which are responsible for the resilience of the territory, have a role to play in the competitiveness process with regard to the responsibility of the government for dealing with disasters. 
Although competitiveness is still associated with the economic aspect, it has its social aspect (Nakamura, 2013). For instance, Glaeser et al. (2001) addressed critical urban amenities as the presence of services and consumer goods, aesthetics and the physical setting, good public services, and speed. Mulligan et al. (2012) insisted that the access of households to private or public services should not be neglected from spatial analysis. Hence, households' welfare needs to be included in the analytical framework when a competitive regional system is examined (Nakamura, 2013). The role of crisis management and building the resilience of the territory precisely lies in this social aspect of competitiveness.

The article focuses on the regional level, so the definition of this term is provided: A region is the functional connection and integration of geographically close urban areas, agglomerations, settlement units, and infrastructural networks characterized by the gradually growing importance of neighborhood contacts. The basis of the region creation is the territorial blending of society and economy and awareness of close interrelatedness between local communities based on historical grounds (Csilla, 2008). In the national concept, a territory is represented by a region of the Czech Republic, 13 regions and the Capital City of Prague.

Territorial competitiveness is based on the capacity of one geographic unit to maintain its medium-term and long-term economic growth, sustained increase in capital investment, product per capita and exports to improve the income and welfare of its population. However, the evaluation of its economic performance must also take into account the quality of its regulatory framework, governmental institutions and actions that favour or hinder the performance of companies, resource availability, infrastructure, innovation capabilities, and all the facilities available to the productive units so they can compete in the best markets of their sector and region (Fernandez et al., 2013).

It follows from the above-stated definition that the mechanism of territorial competitiveness is influenced by a large number of variables and depends on the quality of activities provided by public administration. The slowdown or decline in the competitiveness of the region may be caused by the disaster occurrence and its impacts on the territory. The economic and efficient allocation of funds in the regional budget can contribute to minimizing or avoiding the negative disaster impacts on the competitiveness of the region. If public authorities are not adequately prepared to deal with disasters, the situation in the region will deteriorate, and competitiveness ability will decline. However, if the representatives of the region are aware of this fact and implement it in their decision-making processes, they gain a competitive advantage in the form of increasing resilience of the territory. Based on this finding, the authors of the article aimed at preventing the negative disaster impact on the competitiveness of the region, and therefore introduce a proposal of the mechanism of allocating the optimal amount of funds in the regional budget to DRF.

The literature research carried out showed that the competitiveness of the regions has not yet been examined from the point of view of allocating funds to individual phases of disaster risk management. However, it can significantly contribute to strengthening the social aspect of the regional competitiveness and thereby increasing its attractiveness by providing territorial resilience and prosperity. 


\subsection{Disaster risk financing}

DRF is a proactive approach to disaster risk reduction, which involves early detection of disaster risks and making financial resources available to take care of the needs of the affected communities during and after the disaster to smoothen consumption and engender resilience (Katongole, 2020).

The DRF development is crucial for the governments to accomplish their role in strengthening their respective countries' financial resilience to disaster risks (Juswanto \& Nugroho, 2017; Urban \& Kudlák, 2017). With respect to the financial management of disaster risks, the governments play a key role in developing and designing schemes that enable post-disaster assistance, disaster insurance, and the provision of financial guarantees. Creating a mechanism for providing financial resources for increasing the resilience of the territory can be based on crisis management stages. DRF should cover the financial aspects of all measures of a comprehensive disaster risk management system, which comprises pre-disaster and post-disaster measures (Mita, 2016). Risk prevention measures and preparedness can reduce disaster risks and decrease DRF costs. Furthermore, the DRF availability supports the post-disaster measure implementation such as emergency response, recovery, and reconstruction (Mita, 2016; OECD, 2013). The disproportion between pre-disaster and post-disaster phases (UNISDR, 2015; UNDRR, 2019) demonstrates that society is still under-investing in disaster prevention and anticipation.

Providing safety for the population and territory is one of the essential public goods and services (Jarábková et al., 2016). Financial DRF tool overview includes (Havko et al., 2017; Katongole, 2020; Brugmann, 2012): budget, grants, securitization/structured finance, disaster and social impact bonds; insurance and re-insurance, value capture, performance contracts, custom debt instrument, guarantees and loans.

The mix of financial instruments depends on the disaster management phase as well as on the established legislative and economic conditions in each country. The most widely used instrument for financing disaster risk at the national level is the state budget. For this reason, the appropriate proportion of the government's fiscal expenditure on disaster prevention and mitigation has become a problematic issue of public concern (Sawada \& Takasaki, 2017). If the proportion is too low, it is not conducive to implement disaster-preventing and mitigating measures; if the proportion is too high, it crowds out other investment expenditures, which does not contribute to the sustainable development of the economy and the continuity of government's disaster reduction work (Benali et al., 2016). Therefore, the government's expenditure on disaster prevention and mitigation should be appropriate. However, few scholars have quantitatively analyzed the proportion of financial expenditure on disaster prevention and mitigation, which cannot meet the needs of disaster prevention and mitigation (Wu et al., 2020). The performed scientific literature research showed that there is not enough information on how to efficiently carry out the financing of disaster risks in self-governing territorial units in the Czech Republic.

\subsection{Disaster risk funding approach in the Czech Republic}

The Czech Republic, in its security policy as well as other countries, respond to internationally accepted treaties and commitments in the area of disaster risk reduction. The scientific literature confirms (Juswanto \& Nugroho, 2017; Mita 2016; Wu et al., 2020) that the basis for reducing 
the financial costs associated with disaster risk reduction is the knowledge of the risks of the set territory.

At the central, regional and local levels, public authorities are responsible for providing security and dealing with disasters, as defined by the Crisis Act. The Crisis Act stipulates, inter alia, the obligation for central administrative authorities, regions and municipalities to allocate funds in their budgets to introduce crisis measures.

It was found out by comparing the national DRF possibilities with an international approach that similar methods of financing are used.

The occurrence and impact of an emergency or crisis situation must always be associated with a particular territory (Urban \& Kudlák, 2017) in which damage to the local economy occurs, which worsens financial distress and reduces personal consumption, including disruption of trade and infrastructure of the territory (Bourdeau-Brien \& Kryzanowski, 2019). Consequently, the regional level of disaster management is crucial in relation to building and developing the resilience of territory, its competitiveness, and thus motivating for the population by the socioeconomic offer. It is capable of locally implementing a disaster risk reduction strategy and policy, allocating the necessary resources, including finance and logistics, to secure them (Foltin et al., 2015).

\section{RESEARCH OBJECTIVE, METHODOLOGY AND DATA}

An analysis of the scientific literature shows that the competitiveness of regions has not yet been examined in terms of disaster risk reduction and allocation of public funds to its individual stages. Competitiveness indices of regions are focused on measurable criteria, especially market, economic and social. They do not contain issues of territorial resilience to disasters. Another factor that requires the addressing of this issue is the national legal obligation to allocate funds for disaster preparedness and management. Normative legal acts do not set any minimum amount or method of calculation. It was found out from the survey conducted at the regional level that the regions do not use any calculation that would be based on data, and they only use their qualified estimate.

The aim of the article, which is based on the analysis of regional budgets in the seven-year period, is to define the criteria that must be considered when planning funds for disaster risk management and to propose an original procedure for calculating the minimum number of financial resources at the regional level. The proposed calculation procedure was subsequently verified for all regions in the Czech Republic, and the results were compared with regional budgets.

The research described in the article addresses the following research questions:

1. Are the requirements of the Crisis Management Act for the financial security of the phases of prevention, adjustment, implementation and correction of a disaster fulfilled in all regions of the Czech Republic?

2. Is the amount of allocated funds diversified between regions? 
The article is based on a comparative analysis of the individual phases of crisis management financing in 13 regions in the Czech Republic in the 2013-2019 period. The input data was obtained by analyzing the expenditure parts of the budgets of the regions of the Czech Republic using the information portal of the Ministry of Finance MONITOR. The final data set contained 392 items on disaster financing in individual regions. Basic descriptive statistics and frequency analysis were used for processing this data, which created the preconditions for formulating a conclusion. The number of inhabitants in the region and other data on the region was obtained from publicly available sources, the portal of the Czech Statistical Office. Using comparative analysis, the structure and amount of expenditure, which was allocated to addressing crisis situations at the level of individual regions, were examined. The research was focused on obtaining results showing whether local governments, when drawing up a budget for crisis management in their decision-making process, prefer the allocation of resources for these cases or try to deal with them ex-post and do not plan resources.

\section{RESULTS AND DISCUSSION}

\subsection{Financing the prevention, adjustment, implementation and correction phases of the disaster risk reduction at the regional level}

The development of budget values in individual regions in the monitored period for the prevention phase has a fluctuating tendency, as shown in Figure 1. After a significant decrease in 2016, there was a gradual increase thanks to the obtained subsidy titles both from the state budget of the Czech Republic and the European Union. It can be stated that this is a positive result. However, it does not represent a permanent systemic approach that could have a longterm and stable influence on developing this area of funding.

The same fluctuance as in the prevention phase is also evident for the adjustment phase, see Figure 2. The cause of the fluctuation in 2015 was not detected. No significant crisis situations or changes in legislative requirements for adjustment phase financing occurred in the previous period. For the adjustment phase, less money was spent from the level of regions than for the prevention phase. The ratio between these two phases was differentiated and fluctuated in the monitored period both in the individual region and between regions.

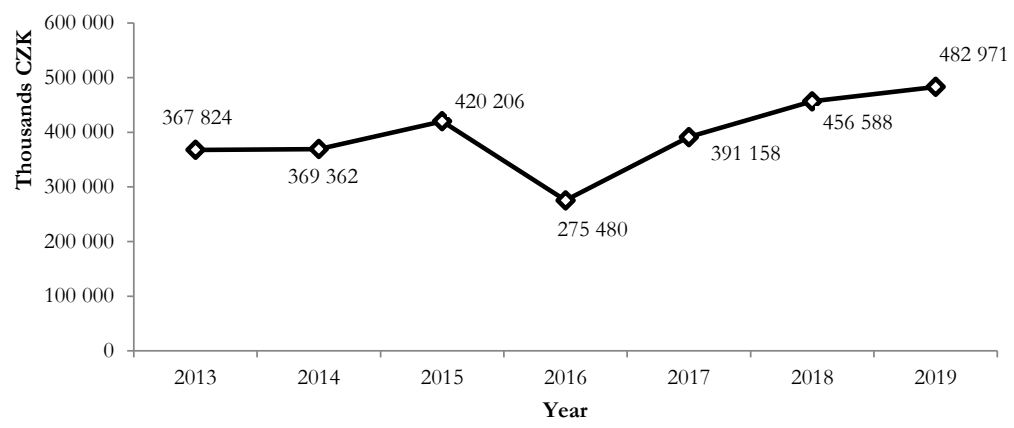

Fig. 1 - Total expenditure on the prevention phase in regions in2013-2019. Source: own research 


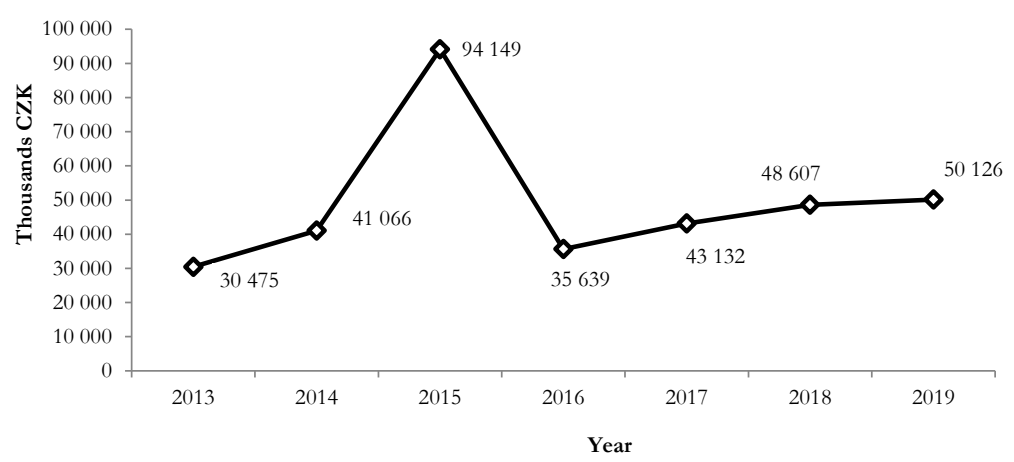

Fig. 2 - Total expenditure on the adjustment phase in regions in2013-2019. Source: own research

On average, the regions allocated $6.735 \%$ of their total budget for the prevention and adjustment phase.

Analysis of expenditures for the implementation phase revealed that until 2018 the development had a slightly fluctuating tendency, see Figure 3. In 2019, a systemic measure of the state was adopted to extend the mandatory structure of security expenditure budgeting, which led to a significant increase in planned resources. Territorial self-governing units started to plan in a new way the fund reserve for crisis measures. However, there is still a lack of standardized rules on how to calculate the necessary value for the discussed crisis resolution periods. In the system of resource planning at the level of regions, due to the government regulation, the planned expenditures were shifted from the adjustment or correction phase to the implementation phase, which seemed to be an increase. However, the volume of planned resources remained unchanged. Expenditures on the correction phase, see Figure 4, are dependent on the occurrence of extraordinary events and crisis situations in the regional area. In the monitored period, no crisis situation was declared on the territory of any region in 2015, 2018 and 2019. Expenditures for the correction phase were lower.

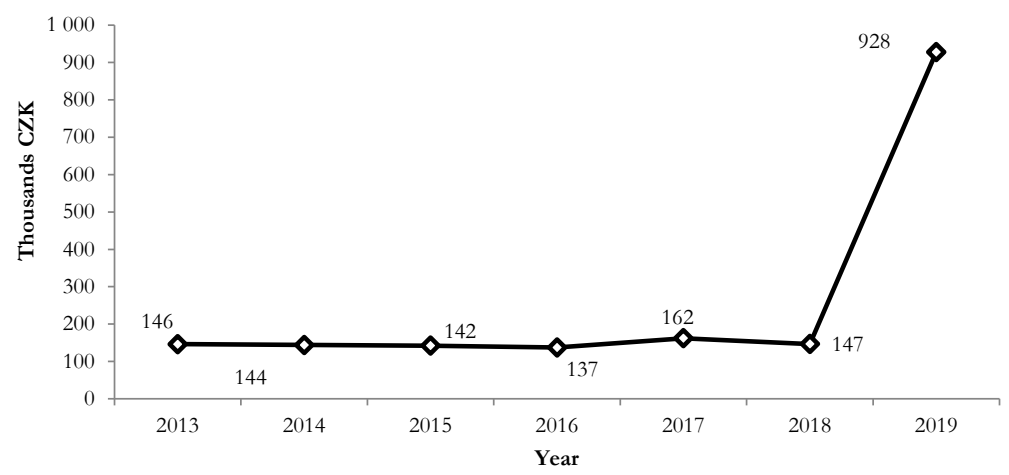

Fig. 3 - Total expenditure on the implementation phase in regions in2013-2019. Source: own research 


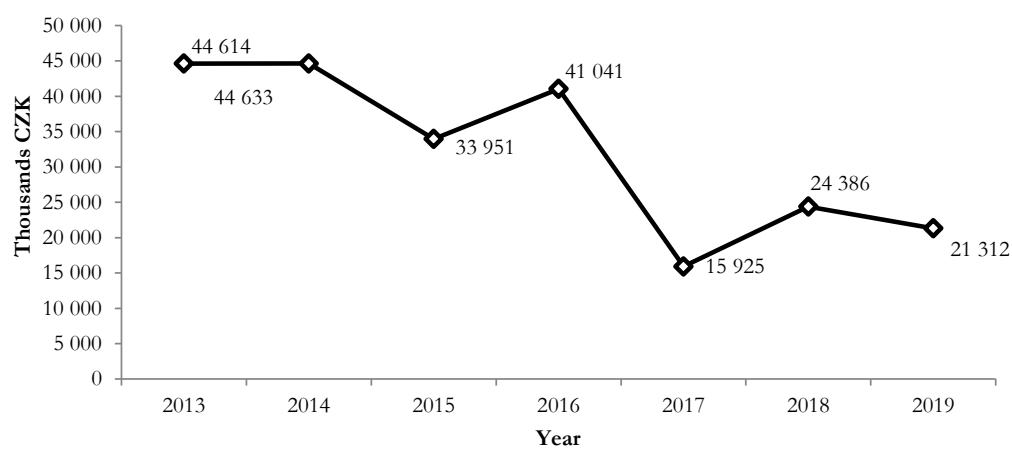

Fig. 4 - Total expenditure on the correction phase in regions in 2013-2019. Source: own research

Not all regions in the Czech Republic met the requirements of the Crisis Management Act on how to financially address the crisis situations. Only units of per cent of the total regional budget were spent financially addressing crisis measures in individual regions. The average value for all regions in the Czech Republic in the observed period was $5.626 \%$.

\subsection{Evaluation of the source support of the territory resilience at the regional level}

Results implied a considerable fluctuation in expenditure within the annual comparison, which may evoke the conclusion that it was not a long-term planned and managed process security. It turned out that management decisions on the amount of allocated funds were rather tendentious and did not guarantee a stable trend line of expenditures on the prevention stage, but declared leaping decision solutions. In addressing the quality of territorial resilience, the most important phase of security is considered to be a phase of prevention that reflects the amount of input into the construction of the security system (Kudlák et al., 2019).

The achieved partial results at the level of individual regions confirmed that a non-systematic approach to allocating resources for dealing with crisis situations in the regional area prevailed, which rejected the first research question. It is desirable to find a unifying allocation key to create a mutual continuous link of resources.

There is currently no percentage, coefficient or amount of financial value set that should be accepted by the regional authorities in the budget to eliminate threats in the region. Likewise, no sanctions for failure to comply with this obligation are set. It can be assumed that for this reason, municipalities allocate funds ad hoc, as a rule, usually ex-post when a crisis situation arises. The prevention phase, which is the decisive basis for the resilience of the territory, is generally underestimated in the annual budgets.

Based on the above-listed facts, it appeared that under current conditions, the regions in the Czech Republic are not able to provide an adequate minimum amount of funds for all phases of crisis management planning in all its phases. The second research question was confirmed. It is therefore desirable to propose a possible procedure to eliminate this disproportion. 


\subsection{Calculation design and its verification}

The results achieved show that it is desirable to find a solution at the regional level to reduce negative impacts of local policy as well as the lack of rules to standardize the support for building a comprehensive resilience of the region. The authors see this as the first step leading to the creation of a stable and long-term support system to establish a unified calculation model that shall be implemented in the process of resource planning at the regional level.

The first step in establishing the procedure for calculating the minimum number of financial resources at the regional level was to define the criteria that must be taken into account when planning financial resources for disaster management. These criteria affect the allocation of financial resources for the resilience of self-governing territorial units. Criteria, which are readily available and consider the risks of disasters in the territory, were chosen. These were the following criteria:

1. The number of inhabitants in the region - the priority task of crisis management authorities is to protect the health and lives that may be affected by their exposure to threats;

2. A total budget of the region, with an emphasis on expenditure - the limited expenditure side of the regional budget must provide coverage of all activities for which the region is responsible. Expenditures of the region are related to providing the economic and social aspects of competitiveness, as they cover, for example, infrastructure repairs, education, culture and health care;

3. The total value of the immovable property of the region on the synthetic account - the property of the region consists of buildings, land, schools and school facilities, cultural facilities, social care facilities, medical facilities, road infrastructure, etc. It may be threatened by a disaster that causes property damage. Restriction or loss of functionality affects territorial competitiveness;

4. A number of crisis situations on the regional territory included in the crisis plan of the region - the number is based on the performed analysis and threats for the region. Based on risk management, unacceptable risks were estimated. Solution procedures were developed for them, which are included in the crisis plan of the region. In the event of their activation, the greatest damage is expected, damage to health and lives, property, restrictions on the regional economic activities and the environment, reducing the territorial competitiveness.

5. A number of crisis situations are based on the type of plans based on the analysis of threats for the Czech Republic.

The proposed criteria for standardizing the calculation of the minimum number of financial resources required in regional budgets are identical with the level of municipalities (Kudlák et al., 2019). The proposed criteria create an objective planning base that reflects the actual situation as well as the specificity of possible threats in the area of the individual regions.

In the second step, the calculation of the minimum allocation of funds for regions was proposed. A methodical procedure for calculating resources at the municipal level was used to propose the calculation of the minimum volume of financial resources at the regional level (Kudlák et al., 2019). A change was made to define values in the denominator, which is based on the total 
planned expenditure of the region on crisis management and on the square root of the territorial size of the self-governing unit, which is a constant value for each region. The modification of the calculation accentuates the statutory responsibility of the region for the administered area. The calculation algorithm was defined by formula (1):

$F=1+\frac{\left(N_{C S}+N_{R C S}\right) \cdot V_{I A}}{\sqrt{T_{a a}} \cdot T_{e r}}$

Where:

F - Financial security of crisis measures

$\mathrm{V}_{\mathrm{IA}}$ - Value of immovable assets (stocktaking and accounting value as of 31 December of the planned year, or current accounting balance) stated in a positive integer. In our case, it is given in Czech crowns

$\mathrm{N}_{\mathrm{CS}}$ - A number of crisis situation types taken out of the total number of 22 as specified and approved by the ministries and other central administration bodies

$\mathrm{N}_{\mathrm{RCS}}$ - A number of (relevant) crisis situation types that may appear in the assessed area of the region (based on the risk analysis for the assessed area as a part of the crisis plan of the region)

$\mathrm{T}_{\mathrm{aa}}$ - The total administrative area of the region

$\mathrm{T}_{\text {er }}$ - The total expenditure of the regional budget per calendar year (capital and current expenditure)

This approach would make it possible to eliminate the unequal approach and differences in the development in resilience increase both of the territory and within individual regions.

In order to verify the functionality of the proposed algorithm (1), recalculation of the planned expenditures for individual phases of disaster management was carried out for all regions for the 2013-2019 period. The calculated results were compared with the actual budgets of the regions. An example of a comparison of the results for 2018 is given in Table 1 and Table 2. The results for the period under research showed that sufficient funds were earmarked in all regions for the prevention and adjustment phases. The biggest problems in the regions were associated with the financing of the implementation phase. Only 3 regions on average earmarked funds for the implementation phase in the 2013-2018 period. Until 2018, on average, all regions earmarked CZK 146,397 for the implementation phase. In 2019, with the above-mentioned legislative change, the situation improved, and 9 regions started to earmark funds for the implementation phase. Based on the calculation made by the proposed formula (1), regions should, on average, plan CZK 6,848,094, which is a significant increase compared to the previous period. Although this represents a significant increase, funding for the implementation phase represents on average only $0.09 \%$ of expenditures for all regions. In the period under research, individual regions planned funds for the correction phase mostly at the same amount. Some regions did not plan any funds for the correction phase at all. Comparison of planned and calculated values after the correction phase suggests that the planned sum of the partial values in individual regions in 2013, 2014, 2015, 2016 and 2018 was higher than the calculation according to the proposed formula (1). 
The results for 2019 showed that, on average, the region should plan CZK 137,664,426 for the prevention and adjustment phase, CZK 8,604,027 for the implementation and CZK 25,812,080 for the correction phase. This average distribution of planned financial resources for the region emphasizes the pre-disaster phase.

Tab. 1 - Comparison of regional budget results with the calculation according to the proposed formula for 2018. Source: own research

\begin{tabular}{|c|c|c|c|c|c|c|c|c|}
\hline \multirow{3}{*}{$\begin{array}{l}\text { Name of the } \\
\text { region }\end{array}$} & \multicolumn{8}{|c|}{ Source allocation in the regional budget - 2018 calendar year } \\
\hline & \multicolumn{2}{|c|}{$\begin{array}{l}\text { Financial security of } \\
\text { crisis measures - total }\end{array}$} & \multirow{2}{*}{$\begin{array}{l}\text { Prevention } \\
\text { phase } \\
\text { (CZK) }\end{array}$} & \multirow{2}{*}{$\begin{array}{l}\text { Adjustment } \\
\text { phase } \\
\text { (CZK) }\end{array}$} & \multirow{2}{*}{$\begin{array}{l}\text { Preven- } \\
\text { tion and } \\
\text { adjustment } \\
\text { phases } \\
(\%)\end{array}$} & \multicolumn{2}{|c|}{ Implementation phase } & \multirow{2}{*}{ 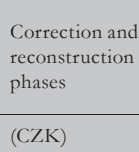 } \\
\hline & $(\mathrm{CZK})$ & $(\%)$ & & & & $(\mathrm{CZK})$ & $(\%)$ & \\
\hline South Bohemian & $654,436,000$ & 3.93 & $645,370,000$ & $9,066,000$ & 3.93 & 0 & 0 & $5,000,000$ \\
\hline South Moravian & $650,859,000$ & 9.19 & $529,547,000$ & $121,312,000$ & 9.19 & 0 & 0 & $10,000,000$ \\
\hline Karlovy Vary & $258,484,000$ & 4.20 & $237,734,000$ & $18,950,000$ & 4.17 & $1,800,000$ & 0.03 & $2,500,000$ \\
\hline Hradec Králové & $361,898,000$ & 8.70 & $359,398,000$ & $2,500,000$ & 8.70 & 0 & 0 & 462,000 \\
\hline Liberec & $285,916,000$ & 9.42 & $241,224,000$ & $39,692,000$ & 9,25 & 0 & 0 & $5,000,000$ \\
\hline $\begin{array}{l}\text { Moravian } \\
\text { Silesian }\end{array}$ & $956,051,000$ & 10.22 & $747,509,000$ & $208,542,000$ & 10.22 & 0 & 0 & 0 \\
\hline Olomouc & $399,388,000$ & 7.35 & $365,962,000$ & $33,319,000$ & 7.35 & 107,000 & 0.001 & 0 \\
\hline Pardubice & $405,788,000$ & 9.20 & $382,843,000$ & $22,945,000$ & 9.20 & 0 & 0 & $3,000,000$ \\
\hline Plzeň & $527,140,000$ & 9.35 & $466,580,000$ & $60,560,000$ & 9.35 & 0 & 0 & $1,000,000$ \\
\hline $\begin{array}{l}\text { Central Bohe- } \\
\text { mian }\end{array}$ & $587,166,000$ & 2.54 & $515,166,000$ & $42,000,000$ & 2.41 & 0 & 0 & $30,000,000$ \\
\hline Ústí nad Labem & $545,580,000$ & 3.26 & $510,900,000$ & $34,680,000$ & 3.28 & 0 & 0 & 60,000 \\
\hline Vysočina & $634,497,000$ & 6.06 & $621,517,000$ & $12,980,000$ & 6.06 & 0 & 0 & $260,000,000$ \\
\hline Zlín & $337,239,000$ & 3.05 & $311,899,000$ & $25,340,000$ & 3.05 & 0 & 0 & 0 \\
\hline $\begin{array}{l}\text { Average of the } \\
\text { total sum }\end{array}$ & $505,341,692$ & 5.33 & $456,588,384$ & $48,606,615$ & 6.63 & $146,692.3$ & 0.002 & $24,386,308$ \\
\hline
\end{tabular}

Tab. 2 - Comparison of regional budget results with the calculation according to the proposed formula for 2018. Source: own research

\begin{tabular}{|c|c|c|c|c|c|c|c|}
\hline \multirow[t]{3}{*}{$\begin{array}{l}\text { Name of the } \\
\text { region }\end{array}$} & \multicolumn{7}{|c|}{ Calculation according to the proposed formula - 2018 calendar year } \\
\hline & \multicolumn{2}{|c|}{$\begin{array}{l}\text { Financial security of crisis } \\
\text { measures- total }\end{array}$} & \multirow{2}{*}{$\begin{array}{l}\text { Prevention } \\
\text { and adjust- } \\
\text { ment phases }\end{array}$} & \multirow{2}{*}{ 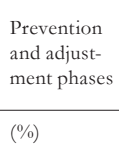 } & \multicolumn{2}{|c|}{ Implementation phase } & \multirow{2}{*}{$\begin{array}{l}\text { Correction } \\
\text { and recon- } \\
\text { struction } \\
\text { phases }\end{array}$} \\
\hline & $(\mathrm{CZK})$ & $(\%)$ & & & $(\mathrm{CZK})$ & $(\%)$ & \\
\hline South Bohemian & $227,835,383$ & 1.37 & $182,268,306$ & 1.10 & $11,391,769$ & 0.07 & $34,175,308$ \\
\hline South Moravian & $110,441,576$ & 1.56 & $88,353,260$ & 1.25 & $5,522,079$ & 0.08 & $16,566,236$ \\
\hline Karlovy Vary & $130,103,221$ & 2.12 & $104,082,576$ & 1.69 & $6,505,161$ & 0.11 & $19,515,483$ \\
\hline Hradec Králové & $103,719,935$ & 2.49 & $82,975,948$ & 2.00 & $5,185,997$ & 0.12 & $15,557,990$ \\
\hline Liberec & $78,697,312$ & 2.59 & $62,957,849$ & 2.07 & $3,934,866$ & 0.13 & $11,804,597$ \\
\hline $\begin{array}{l}\text { Moravian } \\
\text { Silesian }\end{array}$ & $162,887,501$ & 1.74 & $130,310,000$ & 1.30 & $8,144,375$ & 0.09 & $24,433,125$ \\
\hline Olomouc & $95,141,209$ & 1.75 & $76,112,967$ & 1.40 & $4,757,060$ & 0.09 & $14,271,181$ \\
\hline
\end{tabular}




\begin{tabular}{|l|l|l|l|l|l|l|l|}
\hline Pardubice & $107,604,473$ & 2.44 & $86,083,578$ & 1.95 & $5,380,224$ & 0.12 \\
\hline Plzeň & $91,640,465$ & 1.63 & $73,312,371$ & 1.30 & $4,582,023$ & 0.08 \\
\hline $\begin{array}{l}\text { Central } \\
\text { Bohemian }\end{array}$ & $295,984,013$ & 1.28 & $236,787,210$ & 1.02 & $14,799,201$ & 0.06 \\
\hline Ústí nad Labem & $266,864,475$ & 1.60 & $213,491,580$ & 1.28 & $13,343,224$ & 0.08 & $43,746,070$ \\
\hline Vysočina & $154,570,530$ & 1.48 & $123,656,424$ & 1.18 & $7,728,527$ & 0.07 & $40,029,671$ \\
\hline Zlín & $193,881,394$ & 1.75 & $155,105,115$ & 1.40 & $9,694,070$ & 0.09 & $23,185,580$ \\
\hline $\begin{array}{l}\text { Average of the } \\
\text { total sum }\end{array}$ & $155,336,268$ & 1.64 & $124,269,014$ & 1.46 & $7,766,813$ & 0.09 \\
\hline
\end{tabular}

\section{DISCUSSION}

Although research in the field of DRF has progressed and its role is undeniable, the authors have not been able to find any scientific literature that would specifically suggest how to optimally calculate funds for individual phases of disaster management. The differentiated method of DRF results from different systems of public administration, crisis management organization and its financing in individual countries. However, there is a consensus that the funding allocation of the individual phases within the budget is an objective requirement.

There are several studies focused on competitiveness among regions (Lengyel, 2016; Zeibote et al., 2019; Havko et al., 2017; Kellett \& Caravani, 2013; Oprea \& Bilan, 2015). As such, the competitiveness of a region depends on its ability to anticipate and successfully adapt to internal and external economic and social challenges by providing new economic opportunities. Nowadays, competition between regions and consequently the examination of regional competitiveness has become a research question of outstanding importance. The outbreak of the COVID-19 pandemic has sharply and in long-term horizon reduced the competitiveness of industries, regions and entire countries, as evidenced by some studies (Schwab \& Zadihi, 2020; Ilinova et al., 2021; Kurbucz, 2020; Baştuğ \& Yercan, 2021; Caballero-Morales, 2021). The current COVID-19 pandemic has highlighted the fundamental issues of crisis situation resource support.

The paper deals with a unique view of the neglected phase of DRF. International comparison is difficult. The aim of the research is special since the article presents an original proposal of the up-to-now missing standardized definition of the minimum extent of fund allocation in the regional budget for dealing with crisis situations, which respects the specifics of individual regions (occurrence and impact of threats, number of inhabitants, etc.). Each country/municipality is able to allocate a different amount to these phases, and their ability to be resilient is therefore different (Havko et al., 2017). The authors included objective and measurable parameters in the calculation proposal, which are based on risk management and the financial and budgetary possibilities of the region. The inclusion of measurable competitiveness parameters is often problematic, as reported by Huggins et al. (2019). The overall fiscal revenues and expenditures can reflect, by their dimension, structure and dynamics, both the basic guidelines of public authorities' financial policy and the objective or subjective constraints that may act at the same moment. It must be admitted, however, that the influence factors and interpretations for each of the public budgets can bear different meanings, justified by the inherent differences concerning 
the mission of the components under consideration, the administrative level at which they may be found, the competence of the authorities managing them or the specific regulations that govern them (Oprea \& Bilan, 2015).

\section{CONCLUSION}

It has been proved that building a resilient, competitive society and a territory resilient to disasters is not possible without an established and operational financial support mechanism. Creating a financial mechanism for disaster risk reduction is the responsibility of each state, with the emphasis being placed on the pre-disaster phase. In the field of population protection and resilience building, as in other areas of public administration, the principle of subsidiarity based on decentralized responsibility, which can guarantee a high level of security and protection for each citizen, should be applied.

The Act on Crisis Management in the Czech Republic imposes the obligation of financial provision of crisis situations on central administrative authorities and self-governing territorial units. The budget intended to cover all phases of the crisis management should be autonomous and independent of the political and other objectives of public authority officials.

An analysis of budgets of individual regions showed their fluctuating and unsystematic character. The most neglected phase of disaster financing was the implementation phase. These facts became the reason for creating a calculation model proposal of the minimum amount to support the regional resilience.

The article presents an original proposal of the up-to-now missing standardized definition of the minimum extent of fund allocation in the regional budget for dealing with crisis situations, which respects the specifics of individual regions in the Czech Republic. The results show that if the regions plan their budgets for dealing with disasters according to the presented instrument, both disaster resilience and the structural and functional dynamics of individual elements in the given territory, which in perspective tend to influence the socio-economic level of the territory, will be supported.

Applying the proposed calculation of disaster financing when planning the regional budget creates a sustainable competitive advantage based on optimal planning of financial resources for individual phases of the disaster. This approach is especially important with regard to the limited regional financial resources.

The proposed calculation of the minimum allocation of funds for the resilience of the territory brings applicability for the local governments for optimal budgeting of their resources. It shall also be used by ministries, especially the Ministry of the Interior and Finance when carrying out inspections at the regional level. It enables them to check whether the regions comply with the laws on financial planning and allocate the appropriate amount. The authors of the article have undertaken steps to put through this calculation model into the normative legal acts of the Czech Republic. The scientific community can verify the proposed calculation in the conditions of other states. 


\section{References}

1. Baştuğ, S., \& Yercan, F. (2021). An explanatory approach to assess resilience: An evaluation of competitive priorities for logistics organizations. Transport Policy, 103, 156-166. https://doi.org/10.1016/j.tranpol.2021.01.016

2. Benali, N., Abdelkafi, I., \& Feki, R. (2018). Natural-disaster shocks and government's behavior: Evidence from middle-income countries. International Journal of Disaster Risk Reduction, 27, 1-6. https://doi.org/10.1016/j.ijdrr.2016.12.014

3. Boccard, N. (2021). Analysis of trends in disaster risk. International Journal of Disaster Risk Reduction, 53, 101989. https://doi.org/10.1016/j.ijdrr.2020.101989

4. Bourdeau-Brien, M., \& Kryzanowski, L. (2019). Municipal financing costs following disasters. Global Finance Journal, 40, 48-64. https://doi.org/10.1016/j.gfj.2018.10.004

5. Brodmerkel, A., Carpenter, A. T., \& Morley, K. M. (2020). Federal financial resources for disaster mitigation and resilience in the U.S. water sector. Utilities Policy, 63. https://doi.org/10.1016/j.jup.2020.101015

6. Brown, S., Harris, M. N., \& Taylor, K. (2012). Modelling charitable donations to an unexpected natural disaster: Evidence from the U.S. Panel Study of Income Dynamics, 84 (1), 97-110. https://doi.org/10.1016/j.jebo.2012.08.005

7. Brugmann, J. (2012). Financing the resilient city. Environment and Urbanization, 24 (1), 215-232. https://doi.org/10.1177/0956247812437130

8. Caballero-Morales, S. O. (2021). Innovation as a recovery strategy for SMEs in emerging economies during the COVID-19 pandemic. Research in International Business and Finance, 57, 101396. https://doi.org/10.1016/j.ribaf.2021.101396

9. Csilla, F. (2008). Indicators of territorial competitiveness. In International Conference of Territorial Intelligence "Information, Indicators and Tools". Available at: https://halshs.archives-ouvertes.fr/halshs-00794668/document

10. De Juan, A., Pierskalla, J., \& Schwarz, E. (2020). Natural disasters, aid distribution, and social conflict - Micro-level evidence from the 2015 earthquake in Nepal. World Development, 126 (5), 104715. https://doi.org/10.1016/j.worlddev.2019.104715

11. Fernandez, E., Navarro, J., Duarte, A., \& Ibarra, G. (2013). Core: A decision support system for regional competitiveness analysis based on multi-criteria sorting. Decision Support Systems, 54 (3), 1417-1426. https://doi.org/10.1016/j.dss.2012.12.009

12. Foltin, P., Gontarczyk, M., Świderski, A., \& Zelkowski, J. (2015). Evaluation model of the companies operating within a logistic network. Archives of Transport, 32(4), 21-33.

13. Glaeser, E. L., Kolko, J., \& Saiz, A. (2001). Consumer city. Journal of Economic Geography, 1 (1), 27-50. https://doi.org/10.1093/jeg/1.1.27

14. Havko, J., Mitašová, V., Pavlenko, T., Titko, M., \& Kováčová, J. (2017). Financing the Disaster Resilient City in the Slovak Republic. Procedia Engineering, 192, 301-306.

https://doi.org/10.1016/j.proeng.2017.06.052

15. Huggins, R., Thompson, P., \& Prokop, D. (2019). UK Competitiveness Index 2019. Available at: http://cforic.org/wp-content/uploads/2019/03/UKCI-2019.pdf 
16. Ilinova, A., Dmitrieva, D., \& Kraslawski, A. (2021). Influence of COVID-19 pandemic on fertilizer companies: The role of competitive advantages. Resources Policy, 71, 102019.

https://doi.org/10.1016/j.resourpol.2021.102019

17. Jarábková, J., Majstríková, L., \& Kozolka, T. (2016). Financial Supporting Tools of Rural Tourism Development in Nitra Self-Governing Region. European Countryside, 8 (2), 123-134. https://doi.org/10.1515/euco-2016-0010

18. Juswanto, W., \& Nugroho, S. A. (2017). Promoting Disaster Risk. Financing in Asia and the Pacific. Tokyo: Asian Development Bank Institute.

19. Katongole, C. (2020). The role of disaster risk financing in building resilience of poor communities in the Karamoja region of Uganda: Evidence from an experimental study. International Journal of Disaster Risk Reduction, 45, 101458, https://doi.org/10.1016/j.ijdrr.2019.101458

20. Kellett, J. \& Caravani, A. (2013). Financing Disaster Risk Reduction. A 20-year story of international aid. Washington: GFDRR.

21. Kikuta, K. (2019). Post-disaster Reconstruction as a Cause of Intrastate Violence: An Instrumental Variable Analysis with Application to the 2004 Tsunami in Sri Lanka. Journal of Conflict Resolution, 63 (3), 760-785. https://doi.org/10.1177/0022002717753919

22. Kudlák, A., Urban, R., \& Hošková-Mayerová, Š. (2020). Determination of the financial minimum in a municipal budget to deal with crisis situations. Soft Computing, 24 (12), 8607-8616. https://doi.org/10.1007/s00500-019-04527-w

23. Kurbucz, M. T. (2020). A joint dataset of official COVID-19 reports and the governance, trade and competitiveness indicators of World Bank group platforms. Data in Brief, 31, 105881. https://doi.org/10.1016/j.dib.2020.105881

24. Lengyel, I. (2016). Competitiveness of Metropolitan Regions in Visegrad Counties. Procedia Social and Behavioral Sciences, 223, 357-362. https://doi.org/10.1016/j.sbspro.2016.05.241

25. Ma, C., Baker, A. C., \& Smith, T. E. (2021). How income inequality influenced personal decisions on disaster preparedness: A multilevel analysis of homeowners' insurance among Hurricane Maria victims in Puerto Rico. International Journal of Disaster Risk Reduction, 53, 101953. https://doi.org/10.1016/j.ijdrr.2020.101953

26. Marin, G., \& Modica, M. (2017). Socio-economic exposure to natural disasters. Environmental Impact Assessment Review, 64, 57-66. https://doi.org/10.1016/j.eiar.2017.03.002

27. Marin, G., Modica, M., Paleari, S., \& Zoboli, R. (2021). Assessing disaster risk by integrating natural and socio-economic dimensions: A decision-support tool. Socio-Economic Planning Sciences, 77, 101032. https://doi.org/10.1016/j.seps.2021.101032

28. Marto, R., Papageorgiou, C., \& Klyuev, V. (2018). Building resilience to natural disasters: An application to small developing states. Journal of Development Economics, 135, 574-586. https://doi.org/10.1016/j.jdeveco.2018.08.008

29. Mita, N. (2016). The Development of Disaster Risk Financing Strategies in Japan. Presentation at OECDADBI Seminar on Disaster Risk Financing in Asia. Tokyo: Asian Development Bank Institute.

30. Mohan, P. S., Ouattara, B., \& Strobl, E. (2018). Decomposing the Macroeconomic Effects of Natural Disasters: A National Income Accounting Perspective. Ecological Economics, 146, 1-9. 
https://doi.org/10.1016/j.ecolecon.2017.09.011

31. Mulligan, G. F., Partridge, M. D., \& Carruthers, J. I. (2012). Central place theory and its reemergence in regional science. The Annals of Regional Science, 48 (2), 405-431.

https://doi.org/10.1007/s00168-011-0496-7

32. Nakamura, D. (2013). Spatial Policy for a Competitive Regional System: Economic and Social Infrastructure Elements. Journal of Urban Management, 2 (1), 103-112. https://doi.org/10.1016/S2226-5856(18)30067-0

33. OECD (2013). Disaster Risk Financing in APEC Economies: Practices and Challenges. Survey report. Paris: OECD.

34. Oosterhof, L., Heuvelman, A., \& Peters, O. (2009). Donation to disaster relief campaigns: Underlying social cognitive factors exposed. Evaluation and Program Planning, 32 (2), 148-157. https://doi.org/10.1016/j.evalprogplan.2008.10.006

35. Oprea, F., \& Bilan, I. (2015). An Evaluation of the Economic and Financial Crisis's Impact on Local Budgetary Aggregates: The Romanian Case. Procedia Economics and Finance, 20, 467-477. https://doi.org/10.1016/S2212-5671(15)00098-2

36. Paleari, S. (2019). Disaster risk insurance: A comparison of national schemes in the EU-28. International Journal of Disaster Risk Reduction, 35, 101059. https//doi.org/10.1016/h,uhdrr,2018.12.021

37. Sawada, Y., \& Takasaki, Y. (2017). Natural Disaster, Poverty, and Development: An Introduction. World Development, 94, 2-15. https://doi.org/10.1016/j.worlddev.2016.12.035

38. Schwab, K., \& Zadihi, S. (2020). The Global Competitiveness Report Special Edition 2020: How Countries are Performing on the Road to Recovery. Geneva: World Economic Forum.

39. Sturm, T., \& Oh, E. (2010). Natural disasters as the end of the insurance industry? Scalar competitive strategies, Alternative Risk Transfers, and the economic crisis. Geoforum, 41 (1), 154-163. https://doi.org/10.1016/j.geoforum.2009.09.010

40. Taylor, A., Cartwright, A. \& Sutherland, C. (2014). Institutional Pathways for Local Climate Adaptation: A Comparison of Three South African Municipalities. 1 ed. Paris: Agence Française de Développement.

41. UNDRR (2019). Global Assessment Report on Disaster Risk Reduction. Geneva, Switzerland: United Nations Office for Disaster Risk Reduction (UNDRR).

42. UNISDR (2015). Making Development Sustainable: The Future of Disaster Risk Management. Global Assessment Report on Disaster Risk Reduction. Geneva. Switzerland: United Nations Office for Disaster Risk Reduction (UNISDR).

43. United Nations (2015). A/RES/69/283 Sendai Framework for Disaster Risk Reduction 20152030. Geneva, Switzerland: United Nations.

44. Urban, R., \& Kudlák, A. (2017). Allocation of resources as a management-security risk in the level of municipalities. Krizový manažment, 1 (2017), 24-30.

45. Weber, R., \& Musshoff, O. (2021). Risk-contingent credit for sovereign disaster risk finance. International Journal of Disaster Risk Reduction, 56, 102-105.

https://doi.org/10.1016/j.ijdrr.2021.102105 
46. Wu, X., Wang, Z., Gao, G., Guo, J., \& Xue, P. (2020). Disaster probability, optimal government expenditure for disaster prevention and mitigation, and expected economic growth. Science of The Total Environment, 709, 135888 https://doi.org/10.1016/j.scitotenv.2019.135888

47. Wu, Y. C. (2020). Equilibrium in natural catastrophe insurance market under disaster-resistant technologies, financial innovations and government interventions. Insurance: Mathematics and Economics, 95, 116-128. https://doi.org/10.1016/j.insmatheco.2020.08.006

48. Zeibote, Z., Volkova, T., \& Todorov, K. (2019). The impact of globalization on regional development and competitiveness: cases of selected regions. Insights into Regional Development, 1 (1), 33-47. https://doi.org/10.9770/ird.2019.1.1(3)

49. Zhao, J., Lee, J. Y., Li, Y., \& Yin, Y. -J. (2020). Effect of catastrophe insurance on disasterimpacted community: Quantitative framework and case studies. International Journal of Disaster Risk. Reduction, 43, 101387. https://doi.org/10.1016/j.ijdrr.2019.101387

\section{Contact information}

doc. Ing. Alena Oulehlova, Ph.D.

University of Defence

Faculty of Military Leadership

Department of Military Science Theory

Czech Republic

E-mail:alena.ouleblova@unob.cz.

ORCID: 0000-0003-1685-5137

Ing. Ales Kudlak, Ph.D.

University of South Bohemia

Faculty of Health and Social Sciences

Institute of Radiology, Toxicology and Civil Protection

Czech Republic

E-mail: ales.kudlak@centrum.cz.

ORCID:0000-0001-9613-5150

prof. Ing. Rudolf Urban, CSc.

College of Regional Development and Banking Institute - AMBIS, a.s.

Department of Security and Law

Crech Republic

E-mail:ubn17@centrum.cz.

ORCID:0000-0003-1893-4648

Ing. Eva Hoke, Ph.D.

Tomas Bata University in Zlin

Faculty of Logistics and Crisis Management

Department of Crisis Management

Czech Republic

E-mail: boke@utb.cz.

ORCID: 0000-0003-0059-3961 